\title{
Analisis Strategi Bisnis Toko Meubel Chandra Untuk Meningkatkan Daya Saing Di Bandar Lampung
}

\author{
Hendri Dunan ${ }^{1}$ Ahmad Afandi ${ }^{2}$ \\ ${ }^{1}$ Fakultas Ekonomi dan Bisnis, Universitas Bandar Lampung \\ J1. ZainalAbidinPagarAlam No.26, LabuhanRatu, Kedaton, 35142, Bandar Lampung, \\ Indonesia \\ E-mail: \\ Ahmadafandi444@gmail.com \\ Hendri.dunan@ubl.ac.id
}

\begin{abstract}
ABSTRAK
Daya saing merupakan suatu penopang eksistensi suatu usaha untuk berdiri secara berkelanjutan ditengah pesaing yang sudah berjalan lama berdiri maupun baru berjalan untuk memenangkan persaingan. Tujuan penelitian ini adalah bertujuan untuk menganalisis strategi bisnis yang dapat dilakukan untuk meningkatkan daya saing pada usaha Toko Meubel Chandra di Bandar Lampung. Metode penelitian yang digunakan adalah metode penelitian deskriptif kualitatif. Data yang digunakan dalam penelitian ini adalah data primer dan skunder, teknik pengumpulan data melalui observasi, wawancara, dokumentasi, dan penyebaran kuisioner pada toko meubel chandra. Alat analisis data yang digunakan pada penelitian ini menggunakan Analisis SWOT. Dari hasil Penelitian ini menunjukan bahwa strategi yang efektif berdasarkan analisis matriks SWOT dan Diagram Cartesius SWOT dihasilkan Strategi SO (stenght- Oportunity) dan berada pada Kuadran 1.
\end{abstract}

Kata kunci : Daya Saing, Strategi Bisnis dan SWOT.

\section{ABSTRACT}

Competitiveness is a pillar of the existence of an effort to stand sustainably amid a longstanding and new-running competitor to win the competition. The purpose of this study is to analyze the business strategy that can be done to improve competitiveness in the Chandra Furniture Shop business in Bandar Lampung. The research method used is a descriptive qualitative research method. The data used in this study are primary and secondary data, data collection techniques through observation, interviews, documentation, and questionnaire distribution at the Chandra furniture store. Data analysis tools used in this study using SWOT analysis. The results of this study indicate that an effective strategy based on SWOT matrix analysis and Cartesian SWOT Diagrams produces an SO Strategy (Strength-Opportunity) and is in Quadrant 1.

Keywords: Competitiveness, Business Strategy and SWOT. 


\section{PENDAHULUAN}

Bisnis adalah kegiatan yang tidak lepas dari kehidupan manusia. Meubel merupakan salah satu komoditi yang diproduksi dan diperdagangkan secara global. Banyak cara yang dilakukan oleh pengusaha agar usahanya tetap berjalan mulai dari segi pemasarannya yang unik, hingga promosi-promosi yang ditawarkan serta perusahaan juga di tuntut untuk dapat lebih aktif, kreatif dan inovatif dalam memperkenalkan produk terbaik dari perusahaan. Persaingan yang menjadi kian ketat, seiring derasnya arus perdagangan yang secara otomatis yang membuat kompetisi datang dari segala penjuru baik domestik, regional, maupun global.

Pada saat ini, sudah banyak kita temui usaha yang menjual perlengkapan rumah tangga. Usaha ini menjadi kebutuhan bagi rumah tangga untuk mendesain interior dengan indah serta memberikan kenyamanan pada rumah untuk dapat menunjang aktivitas. Objek pada penelitian kali ini yaitu Usaha Toko Meubel Chandra di Bandar Lampung yang berada di Jl. Laks. malahayati (samping bakso lampung) Teluk Betung Barat, Bandar Lampung. Pemilik usaha ini bernama Bapak Chandra, beliau melanjutkan usaha ini setelah ayahnya meninggal. Usaha ini didirikan dari tahun 2017. Pada tahun 2018 usahanya berkembangan hingga sekarang ini meski kadang mengalami jatuh bangun dalam membangun bisnisnya. Bapak Chandra memulai usahanya dari sebuah keinginannya yang mencoba melanjutkan usaha orang tuanya.

tujuan pada penelitian ini adalah sebagai berikut : "Untuk mengetahui Strategi Bisnis yang dapat dilakukan untuk meningkatkan daya saing yang berkelanjutan pada Usaha Toko Meubel Chandra. 


\section{TINJAUAN PUSTAKA}

Menurut Solihin (2012, p196) strategi bisnis berbeda dengan strategi pada level korporat. Strategi di level bisnis ini lebih menfokuskan untuk meningkatkan posisi bersaing produk atau jasa perusahaan di dalam segmen pasar tertentu

Menurut Joewono (2012: 3) mengatakan bahwa strategi bisnis adalah strategi mencapai tujuan yang sering dianalogikan dengan strategi catur, yang dimana sistematika berfikir, penyusunan rencana, kesigapan melangkah, keberanian mengambil resiko dan gairah untuk memenangkan pertandingan merupakan beberapa karakteristik permainan catur yang relevan dengan praktek pengelolaan bisnis.

menurut Bambang Muhardi (2007:39) Daya saing operasi merupakan fungsi operasi yang tidak saja berorientasi ke dalam (internal) tetapi juga keluar (eksternal), yakni merespon pasar sasaran usahanya dengan proaktif.

menurut Rangkuti (2014): "Strategi bisnis ini juga sering disebut strategi secara fungsional karena strategi ini berorientasi pada fungsi-fungsi kegiatan manajemen, misalnya strategi pemasaran,strategi produksi atau strategi fungsional, strategi distribusi, strategi organisasi, dan strategi-strategi yang berhubungan dengan keuangan”.

Menurut Henry Faizal Noor (Yuli Fitriyanti 2007;400) menyatakan bahwa: "Daya saing adalah kemampuan atau ketangguhan dalam bersaing untuk merebut perhatian dan loyalitas konsumen".

Menurut Tambunan $(2008 ; 5)$ Daya saing dari perusahaan dapat ditentukan oleh banyak faktor, tujuh diantaranya yang sangat penting adalah: keahlian atau tingkat pendidikan pekerja, keahlian pengusaha, ketersediaan modal, sistem organisasi dan manajemen yang baik (sesuai kebutuhan bisnis) 
Menurut Rangkuti (2014): “Analisis SWOT adalah indentifikasi berbagai faktor secara sistematis untuk merumuskan strategi perusahaan”.

Menurut Yusmini (2011:68), "Analisis SWOT adalah suatu bentuk analisis dengan mengidentifikasi berbagai faktor secara sistematis terhadap kekuatankekuatan (Strengths) dan kelemahan-kelemahan (Weakness) suatu lembaga atau organisasi dan kesempatan-kesempatan (Oportunities) serta ancaman-ancaman (Threats) dari lingkungan untuk merumuskan strategi perusahaan.

Menurut RD. Jatmiko, (2003: 30) tujuan penggunaan analisis SWOT adalah, "agar organisasi/perusahaan tersebut mampu memanfaatkan informasi perubahan untuk mendapatkan keunggulan kompetitifnya di masa depan."

(Goh dan Kheng-Hor, 2008). Analisis SWOT yang efektif harus bertujuan meraih pemasaran strategis yang cocok dengan lingkungan internal dan eksternal.

\section{METODOLOGI PENELITIAN}

Jenis penelitian ini dilakukan dengan pendekatan Library Research / pustaka dan Field Research / penelitian lapangan (Habiburrahman,dkk., 2019:42). Desain penelitian yang digunakan dalam penelitian ini adalah desain deskriptif yaitu suatu metode dalam meneliti status sekelompok manusia, suatu objek, suatu set kondisi, suatu sistem pemikiran atau kelas peristiwa pada masa sekarang. Metode analisis yang digunakan pada penelitian ini adalah metode analisis kualitatif.

Jenis data yang digunakan dalam penelitian ini ada dua macam yaitu :

\section{a) Data Primer}

Data primer adalah data yang diperoleh atau dikumpulkan langsung dari sumber pertama. Sumber pertama dalam penelitian ini adalah pemilik Usaha Meubel Chandra di Bandar Lampung. Adapun data primer dalam penelitian ini yaitu : data tentang produk yang dijual, data perkembangan nilai penjualan dan data-data lain yang berhubungan dengan Usaha Meubel.

b) Data Skunder 
Data sekunder adalah data yang diperoleh atau dikumpulkan dari sumber orang lain, misalnya melalui bacaan, sumber pustaka, buku-buku atau dokumen dan literatur-literatur yang berkaitan dengan objek penelitian.

Dalam penelitian ini, teknik pengumpulan data yang dilakukan adalah dengan cara:

1) Observasi

Penulis mengamati langsung ke pemilik Usaha Toko Meubel chandra di Bandar Lampung dan beberapa pemilik industri rumahan yang lain juga yang menjadi pesaing.

2) Wawancara

Penulis melakukan wawancara dengan pemilik Usaha Meubel Chandra di Bandar Lampung dengan mengajukan pertanyaan yang berkaitan dengan strategi bisnis.

3) Dokumentasi

Teknik pengumpulan data yang dilakukan dengan menggunakan dokumen tertulis (hasil penelitian, laporan tertulis, buku literatur, majalah, jurnal dan lain sebagainya) sebagai sumber data penelitian dengan cara melakukan pengelompokan atau klarifikasi data yang berhubungan dengan masalah penelitian.

4) Kuisioner

Pengumpulan data faktual untuk memperoleh data variabel / faktor penghambat (Habiburrahman, dkk., 2018;30) pada Usaha Toko Usaha Meubel chandra di Bandar Lampung. 
HASIL PENELITIAN DAN ANALISIS DATA

Tabel 4.1

Hasil Perbandingan Untuk Faktor Internal Toko Meubel Chandra Dengan

Usaha Pesaing

\begin{tabular}{|c|c|c|c|}
\hline No. & Unsur-unsur Faktor & Nilai & Kekuatan/Kelemahan \\
\hline 1. & $\begin{array}{l}\text { Sangat berpengaruh produk } \\
\text { pembelian kosumen }\end{array}$ & 4 & Kekuatan \\
\hline 2. & Harga terjangkau & 3 & Kekuatan \\
\hline 3. & $\begin{array}{l}\text { Sangat memperhatikan dalam } \\
\text { menentuan harga produk }\end{array}$ & 4 & Kekuatan \\
\hline 4. & Memberikan potongan harga & 3 & Kekuatan \\
\hline 5. & Melakukan iklan & 2 & Kelemahan \\
\hline 6. & Lokasi mudah dijangkau & 4 & Kekuatan \\
\hline 7. & Kurang adanya garansi barang & 2 & Kelemahan \\
\hline 8. & Fasilitas usaha kurang memadai & 3 & Kelemahan \\
\hline 9. & Pelayanan sangat baik & 4 & Kekuatan \\
\hline 10. & Kadang-kadang konsumen mengantri & 3 & Kelemahan \\
\hline 11. & Kemampuan bekerja sangat baik & 4 & Kekuatan \\
\hline 12. & Manajemen keuangan Sangat baik & 4 & Kekuatan \\
\hline
\end{tabular}

Sumber : Data diolah 2020 
Tabel 4.2

Hasil Perbandingan Untuk Faktor Eksternal Toko Meubel Chandra Dengan Usaha Pesaing

\begin{tabular}{|c|l|c|c|}
\hline No. & \multicolumn{1}{|c|}{ Unsur-unsur Faktor } & Nilai & Peluang / Ancaman \\
\hline 1. & $\begin{array}{l}\text { Memperhatikan kemampuan } \\
\text { konsumen dalam membeli }\end{array}$ & 3 & Peluang \\
\hline 2. & $\begin{array}{l}\text { Konsumen seringmembeli produk } \\
\text { banyak }\end{array}$ & 3 & Peluang \\
\hline 3. & Pengiriman pemasok terjadwal & 3 & Peluang \\
\hline 4. & Pengiriman tidak tepat waktu & 2 & Ancaman \\
\hline 5. & $\begin{array}{l}\text { Kualitas barang tidak sesuai yang } \\
\text { dikirim pemasok }\end{array}$ & 3 & Ancaman \\
\hline 6. & memiliki banyak pesaing & 1 & Ancaman \\
\hline 7. & Merasa terganggu adanya pesaing & 2 & Ancaman \\
\hline 8. & Produk sama dengan pesiang & 2 & Ancaman \\
\hline 9. & $\begin{array}{l}\text { Cukup mendukung adanya peraturan } \\
\text { Pemerintah }\end{array}$ & 2 & Ancaman \\
\hline 10. & $\begin{array}{l}\text { Tempat usaha sesuai dengan peraturan } \\
\text { pemerintah }\end{array}$ & 4 & Peluang \\
\hline
\end{tabular}

Sumber : Data diolah 2020

Berdasarkan Tabel 4.1 dan 4.2 hasil perbandingan unsur-unsur faktor internal dan eksternal Toko Meubel Chandra dengan usaha pesaing, maka dapat diketahui faktor-faktor internal yang menjadi kekuatan dan kelemahan serta faktor-faktor eksternal yang menjadi peluang dan ancaman Toko Meubel Chandra. 
Adapun tabel IFAS dan EFAS Toko Meubel Chandra dapat dilihat pada Tabel 4.3 dan 4.4 di bawah ini :

Tabel 4.3

Internal Factor Analysis Summary (IFAS)

\begin{tabular}{|l|c|c|c|}
\hline \multicolumn{1}{|c|}{ Faktor-faktor Internal } & Bobot & Rating & $\begin{array}{c}\text { Nilai } \\
\text { Skor }\end{array}$ \\
\hline Strenght (S) & & & \\
1. Sangat berpengaruh terhadap pembelian & 0,09 & 4 & 0,36 \\
konsumen & 0,07 & 3 & 0,21 \\
2. Harga terjangkau & 0,06 & 4 & 0,24 \\
3. Sangat memperhatikan harga produk & 0,10 & 3 & 0,30 \\
4. Potongan harga & 0,08 & 4 & 0,32 \\
5. Lokasi mudah dijangkau & 0,05 & 4 & 0,20 \\
6. Pelayanan sangat baik & 0,10 & 4 & 0,40 \\
7.Kemampuan bekerja sangat baik & 0,11 & 4 & 0,44 \\
8.Manajemen keuangan sangat baik & & & \\
\hline Sub Total & $\mathbf{0 , 6 6}$ & & $\mathbf{2 , 4 7}$ \\
\hline Weakness (W) & & & \\
1. Kurangnya melakukan iklan & 0,08 & 2 & 0,16 \\
2. Kurang adanya garansi barang & 0,10 & 2 & 0,20 \\
3. Fasilitas usaha kurang memadai & 0,07 & 3 & 0,21 \\
4. kadang-kadang konsumen sering mengantri & 0,09 & 3 & 0,27 \\
\hline Sub Total & $\mathbf{0 , 3 4}$ & & $\mathbf{0 , 8 4}$ \\
\hline Total & $\mathbf{1 , 0 0}$ & & $\mathbf{3 , 3 1}$ \\
\hline
\end{tabular}

Sumber : Data diolah tahun 2020

Berdasarkan perhitungan pada Tabel 4.3 Internal Factor Analysis Summary (IFAS) diatas, diketahui faktor strenght mempunyai total nilai skor 2,47 sedangkan weakness mempunyai total nilai skor 0,84. Adapun total nilai skor keseluruhan faktor internal (kekuatan dan kelemahan) adalah 3,31. Seperti halnya pada IFAS, maka pada faktor-faktor strategi eksternal juga dilakukan identifikasi yang hasilnya ada pada Tabel 4.4 Eksternal Factor Analysis Summary (EFAS) berikut ini : 
Tabel 4.4

Eksternal Factor Analysis Summary (EFAS)

\begin{tabular}{|l|c|c|c|}
\hline \multicolumn{1}{|c|}{ Faktor-faktor Eksternal } & Bobot & Rating & $\begin{array}{c}\text { Nilai } \\
\text { Skor }\end{array}$ \\
\hline Opportunities (O) & & & \\
1.Memperhatikan kemampuan konsumen dalam & 0,13 & 3 & 0,39 \\
membeli & 0,12 & 3 & 0,36 \\
2.Konsumen sering membeli produk banyak & 0,12 & 3 & 0,36 \\
3. Pengiriman pemasok terjadwal & 0,11 & 4 & 0,44 \\
4.Tempat usaha sesuai dengan peraturan pemerintah & & & \\
\hline Sub Total & $\mathbf{0 , 4 8}$ & & $\mathbf{1 , 5 5}$ \\
\hline Threath (T) & & & \\
1.Pengiriman kurang tepat waktu & 0,08 & 2 & 0,16 \\
2.kualitas barang tidak sesuai yang dikirim & 0,09 & 3 & 0,27 \\
3. Memiliki banyak pesaing & 0,08 & 1 & 0,08 \\
4.Merasa terganggu adanya persaingan & 0,09 & 2 & 0,18 \\
5. Memiliki produk yang sama dengan pesaing & 0,09 & 2 & 0,18 \\
6. Cukup mendukung adanya peraturan pemerintah & 0,09 & 2 & 0,18 \\
\hline Sub Total & $\mathbf{0 , 5 2}$ & & $\mathbf{1 , 0 5}$ \\
\hline Total & $\mathbf{1 , 0 0}$ & & $\mathbf{2 , 6 0}$ \\
\hline
\end{tabular}

Sumber : Data diolah tahun 2020

Berdasarkan perhitungan pada Tabel 4.2 Eksternal Factor Anaysis Summary (EFAS) di atas, diketahui faktor Opportunity mempunyai total nilai skor 1,55 dan Threat mempunyai total nilai skor 1,05 dan total nilai keseluruhan faktor eksternal (peluang dan ancaman) adalah 2,60

Selanjutnya nilai total skor masing-masing faktor dapat dirinci, Strenght :2,47 weakness : 0,84, Opportunity : 1,55 dan Threath: 1,05. Sedangkan total nilai skor keseluruhan untuk faktor internal (kekuatan dan kelemahan) adalah :3,31 dan faktor eksternal (peluang dan ancaman) adalah 2,60. 
Diagram cartesius analisis SWOT adalah tahap analisis selanjutnya setelah tabel IFAS dan EFAS dibuat. Berdasarkan tabel IFAS dan EFAS diketahui nilai Strenght : 2,47, nilai Weakness : 0,84 dengan selisih 1,63 dan nilai Opportunity: 1,55 nilai Threath 1,05 dengan selisih 0,5. Dari hasil identifikasi faktor-faktor tersebut maka dapat digambarkan dalam diagram cartesius analisis SWOT yang dapat dilihat pada Gambar 4.1 di bawah ini :

Gambar 4.1

Diagram Cartesius Analisis SWOT Usaha Meubel Chandra

Opportunity $(+1,55)$

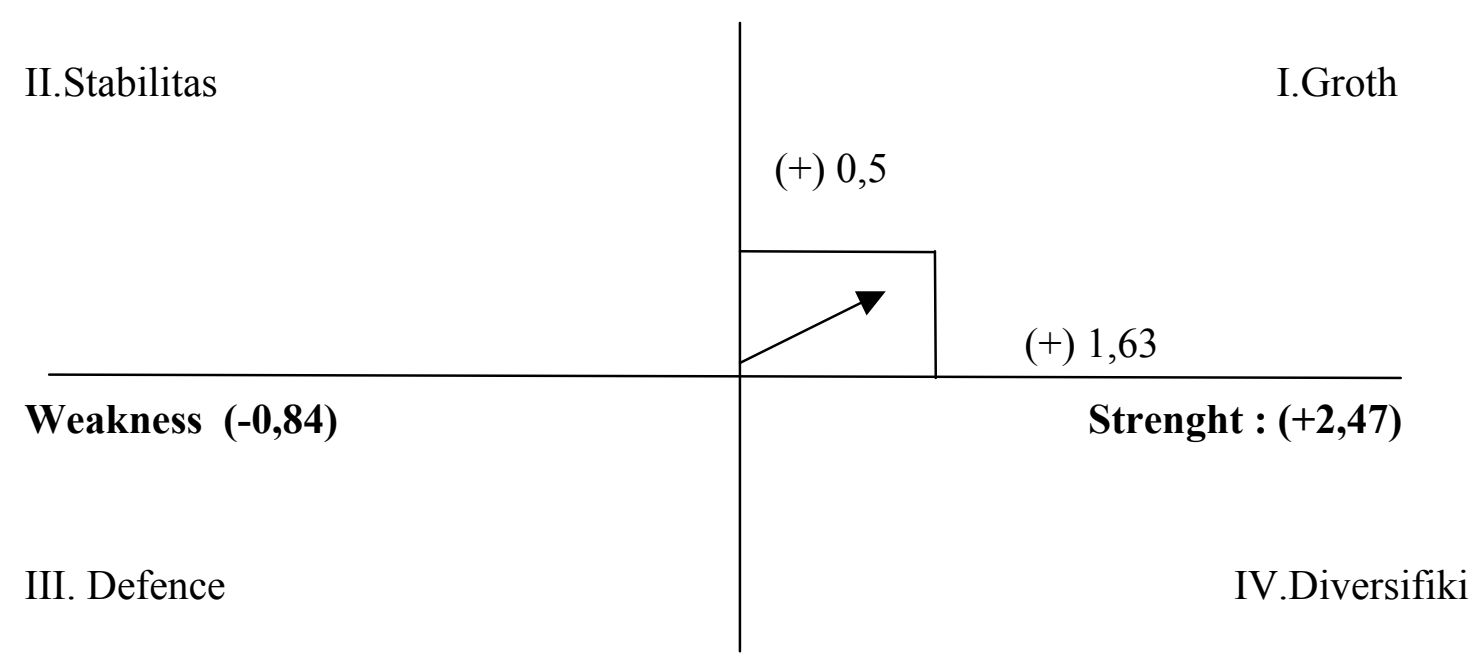

Threat $(-1,05)$

Sumber : data diolah tahun 2020

Berdasarkan diagram cartesius analisis SWOT di atas, diketahui Toko Meubel Chandra berada di kudran 1, di mana situasi yang sangat menguntungkan. Pada kuadran ini, UsahaToko meubel Chandra memiliki peluang dan kekuatan sehingga dapat memanfaatkan peluang yang ada. Strategiyang harus diterapkandalam kondisi ini adalah mendukung kebijakan pertumbuhan agresif (Growth Oriented Strenght),

Adapun analisis matrik SWOT dapat dilihat pada Tabel 4.6 di bawah ini : 
Tabel 4.6

\section{Kombinasi Strategi Matrik SWOT}

\begin{tabular}{|c|c|c|}
\hline Faktor Int & $\begin{array}{l}\text { Strenght (S) } \\
\text { 1. Sangat berpengaruh produk } \\
\text { terhadap pembelian konsumen } \\
\text { 2. Harga terjangkau } \\
\text { 3. Sangat memperhatikan dalam } \\
\text { menentukan harga produk } \\
\text { 4. Memiliki potongan harga } \\
\text { 5. Lokasi mudah dijangkau } \\
\text { 6. Pelayanan sangat baik yang } \\
\text { 7. Kemampuan bekerja sangat baik } \\
\text { 8. Manajemen keuangan sangat baik }\end{array}$ & 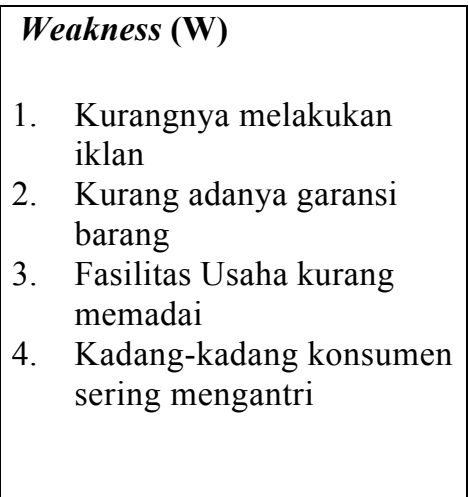 \\
\hline 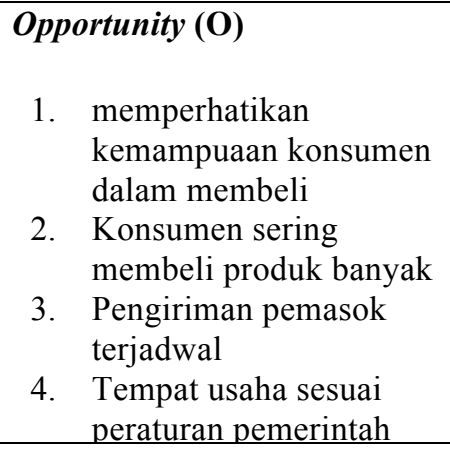 & \begin{tabular}{|l|} 
Strategi (SO) \\
1. Meningkatkan pelayanankonsumen \\
untuk membeli produk dalam jumlah \\
banyak \\
2. Menentukan harga yang terjangkau \\
kepada konsumenagar konsumen \\
membeli dengan jumlah banyak \\
3. Pengiriman yang selalu tepat waktu \\
menjadikan produk selalu tersedia di \\
toko
\end{tabular} & \begin{tabular}{|l|} 
Strategi (WO) \\
1. meningkatkan promosi \\
penjualan \\
2. memberikan garansi kepada \\
konsumen ketika barang \\
yang dibeli cacat \\
3. memberikan fasilitas usaha \\
yang sesuai untuk \\
konsumen agar konsumen \\
membeli produk banyak \\
\end{tabular} \\
\hline $\begin{array}{l}\text { Threath (T) } \\
\text { 1. Pengiriman tidak tepat } \\
\text { waktu } \\
\text { 2. kualitas barang tidak sesua } \\
\text { dengan yang dikirim } \\
\text { pemasok } \\
\text { 3. Memilikibanyak pesaing } \\
\text { 4. Merasa terganggu adanya } \\
\text { persaingan } \\
\text { 5. Memiliki produk yang } \\
\text { sama dengan pesaing } \\
\text { 6. Cukup mendukung adanya } \\
\text { peraturan pemerintah }\end{array}$ & $\begin{array}{l}\text { Strategi ST } \\
\text { 1. Menawarkan produkyang sudah ada } \\
\text { dan memberikan kualitas barang } \\
\text { yang sesuai } \\
\text { 2. Pengiriman danpemesanan bahan } \\
\text { bakuharus tepat waktu danterjadwal } \\
\text { untukmengantisipasiproduk yang } \\
\text { sudahhabis } \\
\text { 3. Meningkatkan kualitas produk agar } \\
\text { lebih unggul dari produk pesaing }\end{array}$ & \begin{tabular}{|l} 
Strategi WT \\
1. Meningkatkan fasilitas toko \\
meubel agar konsumen \\
memiliki kenyamanan saat \\
membeli \\
2. Memberikan kualitas barang \\
yang sesuai kepada \\
konsumen agar konsumen \\
merasa puas
\end{tabular} \\
\hline
\end{tabular}

Sumber : Data diolah tahun 2020

Maka implemetasi dari strategi SO Matriks SWOT tersebut adalah:

1. Meningkatkan pelayanan konsumen untuk membeli produk dalam jumlah banyak.

2. Menentukan harga yang terjangkau kepada konsumen agar konsumen membeli produk dalam jumlah banyak.

3. Pengiriman yang selalu tepat waktu menjadikan produk selalu tersedia di toko. 


\section{KESIMPULAN}

1. Meningkatkan pelayanan konsumen untuk membeli produk dalam jumlah banyak.

2. Menentukan harga yang terjangkau kepada konsumen agar konsumen membeli produk dalam jumlah banyak.

3. Pengiriman yang selalu tepat waktu menjadikan produk selalu tersedia di toko.

4. pemilik usaha dapat menekan jumlah biaya dengan cara membeli jumlah. bahan baku dalam jumlah banyak.

5. memberikan garansi kepada konsumen ketika barang yang dibeli cacat.

6. meningkatkan kembali kualitas produk dan promosi penjualan.

\section{SARAN}

1. Dalam meningkatkan kualitas barang pemilik harus melihat pemasok barang yang dipesan. Untuk mengatasi kesulitan mendapatkan bahan baku dengan kualitas terbaik sebaiknya pemilik harus memperbanyak mitra usaha penyedia bahan baku yang dibutuhkan agar tidak terjadi kekurangan.

2. Dalam menentukan potongan harga sebaiknya pemilik memperhatikan jangkauan konsumen, dalam artian ketika konsumen membeli banyak barang berikan potongan harga yang sesuai dengan pencapaian pembelian tersebut.

3. Dalam menambah stok gudang, perlu adanya pencatatan barang yang terperinci, sehingga pemilik akan mudah dalam memesan barang kepemasok dan akan lebih meningkatkan daya saing yang berkelanjutan. 


\section{DAFTAR PUSTAKA}

Abdul, Solihin. 2012. Analisis Kebijakan. Jakarta: Bumi Aksara

Joewono. (2012). Pengertian Perencanaan Edisi 12 halaman 3.

Muhardi. (2007). Strategi Oprasi: Untuk Keunggulan Bersaing. Yogyakarta.

Faizal Noor, Hendry (2007). Ekonomi Menejerial. Jakarta : PT. Raja Grafindo Persada.

Rangkuti, Freddy. (2014). Analisis SWOT: Teknik Membedah Kasus Bisnis. Jakarta :PT.GramediaPustakaUtama.

Yusmini, dkk. (2011). Analisis Finansial Kud Mandiri Mojopahit Jaya Desa Sari Galuh Kecamatan Tapung Raya Kabupaten Kampar Pekanbaru. Riau:Universitas Riau.

Habibburahman, Iskandar ., Dunan, Hendri., Haninun (2019) Usaha Mikro Kecil dan Menengah (Model Strategi Pemberdayaan dan Pengembangan). Bandar Lampung : Pustaka Media.

Habibburahman, Iskandar AA., Hendri Dunan. (2018). Kewirausahaan Model Strategi Pemberdayaan dan Pengembangan UMKM. Bandar Lampung : Pustaka Media.

Tambunan, Tulus.(2008).Ukuran Daya Saing Koperasi dan UKM'. Jurnal Pusat Studi Industri dan UKM.

Jatmiko, RD. (2003). Manajemen Stratejik. Malang:UMM Press.

Goh, Sunny T.H. -KhooKheng Hor. (2008). Marketing Wise. Jakarta: Gramedia Pustaka. 